\title{
Sociodemographic Characteristics and Smoking Status of Marriage Applicants in Izmit, Turkey
}

\author{
İzmit’te Evlilik Adaylarının Sosyodemografik Özellikleri ve Sigara Kullanım \\ Durumlar1
}

Fatih $\ddot{z c a n}^{* 1}$

ÖZET

Amaç: Ülkemizde evlilik adaylarının sahip oldukları demografik özelliklerin dağılımı hakkında yapılmış araştırmalar sınırlı sayıdadır. Bu nedenle, İzmit’te evlilik adayı kadın ve erkeklerin sosyodemografik özelliklerini saptamak ve bu kișilerin sigara alışkanlıklarını araștırmak amacıyla bu çalıșma planlanmıștır. Gereç ve Yöntem: Araştırmamız, İzmit Ana Çocuk Sağlı̆̆ı ve Aile Planlaması, Üreme Sağlığı Eğitim Merkezi'ne (AÇSAP-ÜSEM) “evlenme öncesi sağlık raporu" için başvuran adaylar arasında gerçekleştirilmiştir. Ağustos - Ekim 2010 tarihleri arasında evlilik ișlemleri nedeniyle tüm başvuranlara tarafımızdan hazırlanan anket yüz yüze uygulanmıştır. Çalışmamızda, irdelenen demografik veriler sırasıyla: yaş, cinsiyet, eğitim durumu, yerleşim yeri, meslek, evlilik sayısı, sigara kullanımı ve günlük sigara tüketimidir. Veriler bilgisayar ortamına girilmiş ve değişkenler arasındaki ilişki istatistiksel olarak araştırılmıştır. Bulgular: Çalışmaya katılan toplam 725 kişinin \%49,4'ü erkek, \%50,6'sı kadın ve yaş ortalaması; 26-49 $\pm 6,28$ idi. Eğitim düzeyi oranı en yüksek grup ilköğretim mezunu olanlar idi $(\% 35,6)$. Meslekler irdelendiğinde, memur veya emeklilerin oranı en yüksek olup $(\% 30,8)$, işsiz olanların oranı ise $(\% 27,4)$ olarak bulunmuştur. Meslek bölümünü “serbest” olarak işaretleyenlerin oranı ise \%6,6'dır. Adayların \%40,6'sı il merkezinde, \%46,9'u Kocaeli'nin İzmit dışındaki ilçelerinden birisinde oturmaktadır. Adayların \%89,7'sinin birinci evliliği olduğu saptanmıştır. Çalışmaya katılan kişilerin \%43,7'si sigara kullanmakta olup, \%56,3'ü ise sigara kullanmamaktadır. Erkeklerin \%56,9'u sigara kullanırken, kadınların \%30,2'si sigara içmektedir (p=0.000). 24 yaş ve altındaki adayların \%37,2'si, 25 yaş ve üzeri adayların ise, $\% 48,1$ 'i sigara kullanmaktadır $(\mathrm{p}=0.004)$. Evlilik sayısı açısından değerlendirildiğinde ise ilk kez evlenenlerin \%41,4'ü sigara içerken, 2 veya daha fazla evliliği olanlarda bu oran \%64 bulunmuştur $(\mathrm{p}=0.000)$. Sonuç: Evlilik adaylarının çoğunluğunun ilkokul mezunu olması, gençlerin evlenmeden önce eğitilmelerinin ve evliliğe hazırlanmalarının önemini göstermektedir. Bu eğitim, hem evlilikle ilgili gerekli sağlık bilgisini, hem kadınlar için annelik bilgisini, hem de ekonomik özgürlüğünü kazanmanın öneminin öncelikle öğretilmesini içermelidir.

Evlilik adaylarının 24 yaş ve altı grubunda sigara kullanma oranı $\% 37,2$ iken 25 yaş ve üstü grupta $\% 48,1$ olması sigara içme oranının yaşla birlikte arttığını göstermektedir. Bu durum, toplumda gelecekteki sağlıklı nesilleri oluşturabilmek için sigara içimini azaltmaya yönelik program ve çabaların önemini ortaya koymaktadır.

Anahtar kelimeler: İzmit’te evlilik adayları, sosyodemografik özellikler, sigara kullanımı

\begin{abstract}
Objective: In Turkey, there are limited number of studies on the distribution of demographic characteristics of marriage applicants. Therefore, we planned this study to determine socio-demographic characteristics of female and male marriage applicants and to investigate their smoking status. Methods: The study was carried out in marriage applicants that applied to the Izmit Mother and Child Care and Family Planning and Reproductive Health Education Center (MCHFP-RHEC) for "premarital health report". All applicants, who applied for marital procedures completed the questionnaire structured by the researchers. The demographic parameters explored within the scope of the study included in turn age, gender, education status, residential area, occupation, number of the current marriage, smoking status and daily cigarette consumption. Data were transferred to the computer, and statistical analysis was performed to determine the relation between variables. Results: Of the 725 study participants, $49.4 \%$ were male, $50.6 \%$ were female, and the mean age was $26.49 \pm 6.28$ years. The majority of the applicants were in the group of primary school graduates $(35.6 \%)$. With regard to the occupation, the ratio of governmental officers and retired subjects was the highest $(30.8 \%)$ followed by unemployed subjects $(27.4 \%)$; the ratio of participants that checked the "self-employment" option was $6.6 \%$. Of the applicants, $40.6 \%$ have been living in the city center, whereas $46.9 \%$ have been living in one of the counties of Kocaeli other than Izmit. It was determined that the current marriage ranks first for $89.7 \%$ of the applicants. While $43.7 \%$ of the study participants were smokers, $56.3 \%$ were nonsmokers. The prevalence of smoking among males and females was $56.9 \%$ and $30.2 \%$, respectively $(\mathrm{p}=0.000)$. Smokers accounted for $37.2 \%$ of the applicants at and under the age of 24 years and $48.1 \%$ of the applicants at and over the age of 25 years $(\mathrm{p}=0.004)$. With regard to the prevalence of smoking according to the rank of the current marriage, it was $41.4 \%$ for those undergoing first marriage, whereas it was found to be $64 \%$ for those undergoing second marriage or more ( $\mathrm{p}=0.000$ ). Conclusion: The fact that primary school graduates account for the majority of marriage applicants, it shows that the importance of preparation and education of those youngsters before get married. This education should include both required general health knowledge for marriage also motherhood for women and teach the importance of acquiring economic freedom firstly. The prevalence of smoking being $37.2 \%$ among the applicants under the age of 24 years and $48.1 \%$ among the applicants at and over the age of 25 years indicates that prevalence of smoking increases with age. This situation exhibits the necessity of smoking reducing programmes and efforts to build healthy generations for the future, in the community.
\end{abstract}

Key words: Marriage applicants in Izmit, sociodemographic characteristics, smoking

Received / Geliş tarihi: 22.10.2016, Accepted / Kabul tarihi: 13.07.2017

${ }^{1}$ Celal Bayar Üniversitesi Tip Fakültesi

*Address for Correspondence / Yazışma Adresi: Fatih Özcan, Celal Bayar Üniversitesi Tıp Fakültesi, Manisa-TÜRKIYYE

E-mail: fatihozcan41@ gmail.com

Ozcan F. Sociodemographic Characteristics and Smoking Status of Marriage Applicants in Izmit, Turkey. TJFMPC, 2017;11(3): 152-158

DOI: $10.21763 /$ tjfmpc.336133

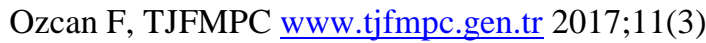




\section{INTRODUCTION}

Marriage is a tradition down the ages and an indispensable period of life. Marriages, for either maintenance of human lineage or continue emotional togetherness by strengthening them, have sometimes prevented battles or led to the changes in the politics of a country. Marriage is a condition that may substantially change not only the populations' and nations', but also the individuals' own lives. Wonder if the individuals act consciously enough at that critical milestone of their lives? Are they ready for marriage? It is usually difficult to answer these questions before marriage. On the other hand, the characteristics of marriage applicants show variation among countries, even among the regions of a country. Considering the education status and distribution of income in Turkey, while some regions are socioeconomically similar, it is known that there are remarkable differences between the others. ${ }^{1}$ Smoking status of the women marriage applicants is important so that they are future mothers; women who smoke cigarette daily time in their normal life, they may continue to smoke in pregnancy. Whereas a mother candidate should not smoke when she is pregnant. During pregnancy, smoking increases the risk of low birth weight infants, placental problems (previa and/or abruption), chronic hypertensive disorders, and fetal death. $^{2}$

Smoking habit is one of the most important public health problems and causes of death all over the world. Despite the fact that unfavorable effects of smoking on health have been documented, the worldwide prevalence of smoking among females is gradually increasing. ${ }^{3}$ In Turkey, there is limited number of studies about demographic characteristics and smoking habits of marriage applicants. In order to make a contribution to the studies performed and the data obtained until today, it was planned to conduct a study in a city located in the western, relatively developed region of Turkey. Izmit is the central county of Kocaeli, which is located relatively in the eastern side of Marmara Region and west part of Turkey, the population of which is 1.560 .138 as province of 2010, and has a population of 315.734 . Kocaeli is one of the highest per capita income provinces in Turkey. It is a province with intensive industrial investment. In the present study, the marriage applicants that applied to Izmit MCHFPRHEC are generally the subjects who have been living within the borders of Izmit County or in the villages around Izmit.
For this reason, the study was planned to determine the sociodemographic characteristics of marriage applicants in Izmit and to investigate their smoking habits.

\section{METHODS}

The present study was carried out in female and male marriage applicants, who applied to the Izmit Mother and Child Health and Family Planning, Reproductive Health Education Center (MCHFPRHEC) for "premarital health report".

This is a descriptive study and carried out between August and October 2010.

Inclusion criteria: to be a marriage applicant and who accepted to participate in study.

Exclusion criteria: not to be a marriage applicant or who does not accept to participate in study.

The study universe is the marriage applicants living in Izmit and surroundings and applied to Izmit MCHFP-RHEC for marital procedures. Among all subjects applied between August and October 2010 for marital procedures, the applicants that have given consent for participation in the study were enrolled in the study. 725 female and male marriage applicants accepted to participate in our study. Content of the questionnaire were some sociodemographic characteristics as age, gender, education status, residential area, occupation, number of the current marriage and smoking status and daily cigarette consumption.

Statistical analyses of the results were done by SPSS statistical software. Chi square test was performed. Statistical significance was accepted as $\mathrm{P}$ $<0.05$. For data collection, the questionnaire was completed by the researcher, midwives and nurses working at Izmit MCHFP-RHEC marriage policlinic together with the marriage applicants via face to face interview. Official permission of Kocaeli Local Health authority was obtained to conduct the study. In addition, verbal consent of each marriage applicant was obtained before completion of the questionnaire, and the applicants who have given consent were asked to complete the questionnaire.

Dependent variables of the study were smoking status, daily cigarette consumption, number of marriage. Independent variables were age, gender, education status, occupation, residential area. In our 
study, all applicants accepted to participate the study.

\section{RESULTS}

Of the 725 study participants, 358 (49.4\%) were male, $367(50.6 \%)$ were female, and the mean age was $26.49 \pm 6.28$ years. The majority of applicants $(35.6 \%)$ were primary school graduates. Regarding occupation, most of the participants are civil servants or retired $(30.8 \%)$ followed by unemployed applicants (27.4\%). "Self-employment" option was checked by $6.6 \%$ of the participants. Of the applicants, $40.6 \%$ have been living in the city center and $46.9 \%$ have been living in one of the counties of Kocaeli other than Izmit (Table 1). It was determined that the current marriage was the first for $89.7 \%$ of the applicants (Table 2). Of the study participants, $43.7 \%$ were smokers, whereas $56.3 \%$ were nonsmokers (Table 3 ). With regard to the genders, $56.9 \%$ of males and $30.2 \%$ of females were smokers $(\mathrm{p}=0.000)$.
Smokers accounted for $37.2 \%$ of the applicants at and under the age of 24 and $48.1 \%$ of the applicants at and over the age of 25 years $(\mathrm{p}=0.004)$. Regarding the number of marriages, $41.4 \%$ of those married for the first time and $64 \%$ of those married for the second or more times were smokers $(p=0.000)$ (Table 4).

According to the educational status of women, $45.7 \%$ of literate/primary school group and $42.6 \%$ of secondary school/ high school and over group were smokers, on the other hand, $54.3 \%$ of literate/primary school group and $57.4 \%$ of secondary school/ high school and over group were nonsmokers. It was insignificant statistically $(\mathrm{p}=$ 0.417) (Table 4). There was no significant difference in smoking status of women with respect to their educational status $(\mathrm{p}=0,772)$.

When stratified analyzis done for demonsrating effect of age, it was seen that the relation was being continued between number of marriage and smoking ( $\mathrm{p}=0,015$ and $\mathrm{p}=0,016)$ (Table 5).

\begin{tabular}{|l|c|c|}
\hline \multicolumn{1}{|c|}{ Table 1. Sociodemographic characteristics of the study population } & \% \\
\hline \multicolumn{1}{|c|}{$\begin{array}{l}\text { Demographic Characteristics } \\
(\mathbf{n}=\mathbf{7 2 5})\end{array}$} & & \\
\hline Gender & 358 & 49.4 \\
\hline Male & 367 & 50.6 \\
\hline Female & & 15.2 \\
\hline Education Status & 110 & 20.4 \\
\hline Primary school & 148 & 35.2 \\
\hline Secondary school & 255 & 13.1 \\
\hline High School & 95 & 16.1 \\
\hline College & 117 & \\
\hline University & & 23.0 \\
\hline Occupation (n=695) & 167 & 30.8 \\
\hline Worker & 223 & 6.6 \\
\hline Officer/retired & 48 & 6.9 \\
\hline Self-employment & 50 & 27.4 \\
\hline Tradesman & 199 & 1.1 \\
\hline Unemployed & 8 & \\
\hline Student & & 40.6 \\
\hline Residential area & 294 & 46.9 \\
\hline City center & 340 & 11.0 \\
\hline County center & 80 & 1.5 \\
\hline Village & 11 & \\
\hline Unknown & & \\
\hline
\end{tabular}




\begin{tabular}{|c|c|c|c|}
\hline \multicolumn{2}{|c|}{ Table 2. Distribution of certain characteristics of the study population } \\
\hline Characteristics & $\mathbf{n}$ & $\mathbf{\%}$ & $\begin{array}{l}\text { Minimum, Maximum, Mean, } \\
\text { Median, SD*, SE* }\end{array}$ \\
\hline Age (n=722) & & & Minimum $=16$ \\
\hline$<18$ & 12 & 1.7 & Maximum $=68$ \\
\hline $18-20$ & 67 & 9.2 & Mean $=26.49$ \\
\hline $21-25$ & 285 & 39.3 & Median $=25.00$ \\
\hline $26-30$ & 242 & 33.4 & SE $=0.234$ \\
\hline $31-35$ & 68 & 9.4 & SD $=6.289$ \\
\hline$\geq 36$ & 48 & 6.6 & Minimum $=1$ \\
\hline Number of current marriage & & & Maximum $=4$ \\
\hline $1^{\text {st }}$ & 650 & 89.7 & Mean $=1.11$ \\
\hline $2^{\text {nd }}$ & 71 & 9.8 & Median $=1$ \\
\hline $3^{\text {rd }}$ & 4 & 0.6 & SE $=0.013$ \\
\hline & & & SD $=0.349$ \\
\hline
\end{tabular}

* SD: Standard deviation, SE: Standard error.

\begin{tabular}{|l|c|c|}
\hline \multicolumn{2}{|l|}{ Table 3. Smoking status of the study population } & n \\
\hline Characteristics & & \% \\
\hline Smoking & 317 & 43.7 \\
\hline Yes & 408 & 56.3 \\
\hline No & & \\
\hline $\begin{array}{c}\text { Daily cigarette } \\
\text { Consumption (pieces) }(\mathbf{n}=\mathbf{3 1 7})\end{array}$ & 69 & 9.5 \\
\hline$<5$ & 115 & 15.9 \\
\hline $5-10$ & 107 & 14.8 \\
\hline $11-20$ & 26 & 3.6 \\
\hline$>20$ & & \\
\hline
\end{tabular}

\begin{tabular}{|c|c|c|c|c|c|}
\hline & & & & $\begin{array}{l}\text { ker } \\
\text { ) }\end{array}$ & p value \\
\hline & $\mathbf{N}$ & $\%$ & $\mathbf{N}$ & $\%$ & \\
\hline Gender & & & & & \\
\hline Male & 209 & 56.9 & 158 & 43.1 & \\
\hline Female & 108 & 30.2 & 250 & 69.8 & \\
\hline Age (years) & & & & & 0.004 \\
\hline$\leq 24$ & 108 & 37.2 & 182 & 62.8 & \\
\hline$\geq 25$ & 208 & 48.1 & 224 & 51.9 & \\
\hline Education level & & & & & 0.417 \\
\hline Literate/Primary school & 118 & 45.7 & 140 & 54.3 & \\
\hline Secondary S/High school and over & 119 & 42.6 & 268 & 57.4 & \\
\hline Number of current marriage & & & & & 0.000 \\
\hline 1 & 269 & 41.4 & 381 & 58.6 & \\
\hline$\geq 2$ & 48 & 64.0 & 27 & 36.0 & \\
\hline
\end{tabular}




\section{DISCUSSION}

In our study, the prevalence of smoking among males and females was $56.9 \%$ and $30.2 \%$, respectively. It may be related to cultural features of our research people.

The fact that primary school graduates accounted for the majority of marriage applicants suggests that education level in young generation has not yet reached to the targeted level in Turkey. Considering that the applicants, who were jobholder or temporary employees, have checked the "selfemployment" option and when the student applicants as well were included in this group, it is seen that the prevalence of applicants with irregular income account for the substantial proportion of the marriage applicants $(6.6 \%+27.4 \%+1.1 \%=$ $35.1 \%$ ). The new family's being destitute of economic power or probably being in need of support of family elders appears not to be a barrier to marriage. Maybe the applicants regard marriage as a good reason to provide economic support. Against the literature, in our study, there was no significant difference in smoking status of women with respect to their educational status. The fact that the prevalence of smoking is higher among the subjects applied for their second marriage or further as compared to those applied for their first marriage is conspicuous. This suggests that smoking habit is enhanced as the number of marriages increased. When stratified analysis statistically applicated to control effect of age, it was observed that the relationship between number of marriage and smoking status become continuing (Table 5).

\begin{tabular}{|c|c|c|c|c|c|c|c|c|}
\hline \multirow[t]{2}{*}{$\begin{array}{c}\text { Age } \\
\text { (years) }\end{array}$} & \multirow{2}{*}{$\begin{array}{l}\text { Number } \\
\text { current } \\
\text { marriage }\end{array}$} & \multicolumn{2}{|c|}{$\begin{array}{l}\text { Smoker } \\
(n=317)\end{array}$} & \multicolumn{2}{|c|}{$\begin{array}{l}\text { Non-smoker } \\
\quad(n=408)\end{array}$} & \multicolumn{2}{|c|}{ Total } & \multirow[t]{2}{*}{ p value } \\
\hline & & $\mathbf{N}$ & $\%$ & $\mathbf{N}$ & $\%$ & $\mathbf{N}$ & $\%$ & \\
\hline \multirow[t]{3}{*}{$\leq 24$} & 1 & 102 & 35.9 & 182 & 64.1 & 284 & 100 & \multirow{3}{*}{0.015} \\
\hline & $\geq 2$ & 7 & 77.8 & 2 & 22.2 & 9 & 100 & \\
\hline & Total & 109 & 37.2 & 184 & 62.8 & 293 & 100 & \\
\hline \multirow[t]{3}{*}{$\geq 25$} & 1 & 167 & 45.6 & 199 & 54.4 & 366 & 100 & \multirow{3}{*}{0.016} \\
\hline & $\geq 2$ & 41 & 62.1 & 25 & 37.9 & 66 & 100 & \\
\hline & Total & 208 & 48.1 & 224 & 51.9 & 432 & 100 & \\
\hline
\end{tabular}

The prevalence of regular smoking was higher among employed versus unemployed females. It was determined that the prevalence of smoking increases as the level of education is increased. This may be due to economic freedom. Gülbayrak et al found results similar results in their research in Elazı $\breve{g}$ city, 2003. ${ }^{4}$

In Turkey, according to TDHS 2013, the mean age at first marriage of women is 21.2 years for women living in urban areas and 20.4 years for women living in rural areas. ${ }^{3}$

According to TDHS 2013, averagely $22 \%$ of females are current smokers although the prevalence of smoking varies according to age. This appears to be increased as compared to the prevalence of smoking in females reported in TDHS 2003. The prevalence of smoking is higher in females living in urban areas and in Istanbul. It increases as the education level is increased; the prevalence of smoking is approximately 2 times higher in females who are at least high school graduates as compare to the lowest education level ( $44 \%$ vs. $21 \%$ ). Likewise, smoking is more common among females of high living standard versus females of low living standard. ${ }^{3}$ In a study conducted in 2008, which investigated the prevalence of smokers and level of nicotine addiction in 3088 governmental officers in Mersin, $48.6 \%$ of the officers were current smokers and the prevalence of smoking was higher in males. ${ }^{5}$

Gülbayrak et al. conducted a study including two training and research primary health care offices in the city center of Elazı $\breve{g}$, and they found the prevalence of regular smoking to be $26.5 \%$ in female participants. The prevalence of smoking in females shows variation among countries, which is low as $7 \%$ in the developing countries but $24 \%$ in the developed countries. $^{4}$ In Turkey, the study 
conducted in 1988 by PIAR determined the prevalence of smoking to be $24.3 \%$ in females. On the other hand, Bilir et al. reported that females establish a risk group in terms of their attitudes and behaviors concerning smoking and that the prevalence of smoking ranges between $12 \%$ and $45 \%$ among females of different occupations. ${ }^{4}$

Karaoğlu et al. conducted a study in 1997 including married females living in the district of a primary health care office in Çorum, and they found that the mean age at first marriage was 17.7 years. ${ }^{6}$ Orak et al. conducted a study in 2000 in Isparta and found that the mean age at first marriage was $19.6 \pm$ 5.17 years for females and $23.43 \pm 4.45$ years for their partners. ${ }^{7}$ Cho et al. carried out a study on smoking in the South Korea and found that the prevalence of smoking is decreased with age in males but, contrarily, increased with age in females. On the other hand, prevalence of smoking was found to be higher in unmarried versus married males and females. Again, in the same study, the prevalence of smoking was found $6.3 \%$ in unmarried females of 25-34 year-age group. In that study, prevalence of smoking was found higher in unmarried males and females as compared to married males and females. ${ }^{8}$ In a study conducted in 81.000 subjects in Sweden, the prevalence of smoking was $27.2 \%$ in females and $29 \%$ in males. ${ }^{9}$

Giordano and Lindström conducted a study between the years 2003 and 2005 in Sweden and found the prevalence of smoking $46.4 \%$ in males and $53.6 \%$ in females. ${ }^{10}$ In a large-scale study carried out between the years 1996 and 2006 by McDermott et al. in Australian females, data from 6840 young females were investigated and the prevalence of current smokers was found to be $16.6 \% .{ }^{11}$ In the US, Homish et al. found the prevalence of smoking to be $32 \%$ in males and $28 \%$ in females. ${ }^{12}$ In our study, probably, first research done in female and male marriage applicants in Turkey.

Strength of this study was the first research in Turkey applying to marriage candidates directly until that time. In the time period of study carriying out, Izmit Mother and Child Health and Family Planning, Reproductive Health Education Center (MCHFP-RHEC) was the only unique establishment in the city for "premarital health report". Those were strengths of our study. It may be remarked as limitations of our study were questioning of the smoking status of study population could had been done more detailed and smoking addiction level evaluated in detailed.

Limitations of our study were it was conducted in only one town, Izmit. If it would be done different places it could be detected more valuable results. In addition, questions and procedures more detailed especially which determines addiction level of smoking could be composed.

\section{CONCLUSION}

Further studies that will be performed in larger patient groups and in different geographic regions are needed to unveil the dynamics and factors underlying the results of the present study, which we conducted in Izmit, an intensive migration-receiving industrial city.

The fact that primary school graduates account for the majority of marriage applicants, it shows that the importance of preparation and education of those youngsters before get married. This education should include both required general health knowledge for marriage also motherhood for women and teach the importance of acquiring economic freedom firstly.

The prevalence of smoking being $37.2 \%$ among the applicants under the age of 24 years and $48.1 \%$ among the applicants at and over the age of 25 years indicates that prevalence of smoking increases with age. Therefore, this situation exhibits the necessity of smoking reducing programmes and efforts to build healthy generations for the future, in the community.

\section{Acknowledgement}

I thank Dr. Berna Ayakta Şerifi for her assistance in statistical analysis and Prof. Dr. Bektaş Murat Yalçın for the critical reading of the manuscript.

*I declare that there is no conflict of interest.

*The abstract of this study took place as oral presentation at the $\mathrm{X}$. National Family Medicine Congress (TAFP) and in Fethiye, Turkey on 18-22 May 2011.

\section{REFERENCES}

1. Yılmazçoban AM. The factors that effect couples in marriage and principles of friendship. 
Yalova Sosyal Bilimler Dergisi 2011; (1): 17895.

2. Phelan S. Smoking cessation in pregnancy. Obstetrics and Gynecology Clinics 2014; 41(2): 255-266.

3. Türkiye Nüfus ve Sağlık Araştırmas-2013 (Demographic and Health Survey of Turkey), Hacettepe Üniversitesi Nüfus Etütleri Enstitüsü. Ankara, Turkey 2014; 132-33.

4. Gülbayrak C, Açık Y, Deveci SE, Oğuzöncül AF. Smoking frequency of the women in two training and research health regions in Elazı $\breve{g}$ city centre. Erciyes Medical Journal 2004; 26 (4): 158-64.

5. Buğdaycı R, Şaşmaz T, Gökçe H, Kutay S, Gökdemir H. Prevalence of smoking and addiction levels among government Mersin province Turkey. Turkish Journal of Public Health 2010; 8 (2): 74-82.

6. Karaoğlu L, Öztürk C, Pehlivan E. Fertility and its determinants among married women living in the responsibility area of a health unit in Çorum. Journal of Turgut Ozal Medical Center 2002; 9 (1): 33-40.

7. Orak S, Korkmaz M, Orhan M. The study of health and sociodemographic knowledge of married women in binbirevler quarter, Isparta. Süleyman Demirel Üniversitesi Yaşam Dergisi 2009; 1 (1): 8-13.

8. Cho HJ, Khang YH, Jun HJ, Kawachi I. Marital status and smoking in Korea: the influence of gender and age. Social Science \& Medicine 2008; 66 (3): 609-19.

9. Paul Nystedt. Marital life course events and smoking behaviour in Sweden 1980-2000. Social Science \& Medicine 2006; 62 (6): 142742.

10. Giordano GN, Lindstro M. The impact of social capital on changes in smoking behaviour: a longitudinal cohort study. The European Journal of Public Health Advance 2010; 21 (3): 347-54.

11. McDermott L, Dobson A, Owen N. Determinants of continuity and change over 10 years in young women's smoking. Addiction 2009; 104 (3): 478-87.

12. Homish GG, Leonard KE. Spousal influence on smoking behaviors in a US community sample of newly married couples. Social Science \& Medicine 2005; 61 (12): 2557-67. 